\title{
Geotechnical and Chemical Evaluation of Tropical Red Soils in a Deltaic Environment: Implications for Road Construction
}

\author{
Akaha C. Tse ${ }^{1} \&$ Adunola O. Ogunyemi ${ }^{1}$ \\ ${ }^{1}$ Department of Geology, University of Port Harcourt, Nigeria \\ Correspondence: Akaha C. Tse, Department of Geology, University of Port Harcourt, Nigeria. Tel: \\ 234-8055-364-149. E-mail: akaha.tse@uniport.edu.ng
}

Received: December 10, 2015

Accepted: December 30, 2015

Online Published: August 30, 2016

doi:10.5539/jgg.v8n3p42

URL: http://dx.doi.org/10.5539/jgg.v8n3p42

\begin{abstract}
Tropical red soils which occur in the dry flatlands and plains of the eastern Niger Delta Nigeria were evaluated using combined conventional engineering geological investigation with major oxide geochemistry to determine their properties and evaluate their engineering performance in road construction. Laboratory test results indicate that the brownish materials are uniformly graded, silty clayey sandy soils. The silica to sesquoxide ratio values of 3 to 4.37 indicate that they are non-lateritic tropically weathered soils. The average values of the specific gravity, liquid limit, plasticity index and shrinkage limits are $2.67,37 \%, 10 \%$ and $7.6 \%$ respectively. They are soils of low to medium plasticity. The unsoaked and soaked CBR values range from $14-38 \%$ and $3-9 \%$ respectively whereas the average undrained shear strength is $172 \mathrm{kN} / \mathrm{m}^{2}$. Maximum dry density and optimum moisture content values fall between 1680 to $1880 \mathrm{kN} / \mathrm{m}^{2}$ and $13-16 \%$ respectively. Generally the soils classify as A-7-6 to A-2-4 subgroups of the AASHO classification. The overall implication of these composite engineering properties is that the non-lateritic soils rate as poor to fair subgrade materials.
\end{abstract}

Keywords: geotechnical, red soils, sesquioxide, lateritic, subgrade, Niger Delta

\section{Introduction}

The Niger Delta wetland area in Nigeria consists of three geomorphologic zones including the coastal or Lower delta zone, Transition or Mangrove zone and the Upper deltaic plain or freshwater zone. The freshwater zone consists of dry flatlands and plains (Akpokodje 1989 and Teme 2002) and its subsurface soil profile consists of a top lateritic clay layer underlain by silty clays and sands which are in turn succeeded by poorly graded sand and gravel. Akpokodje (1989) described the lateritic layer as a reddish brown/brown soft to firm clay which becomes stiffer with depth and is mottled with shades of grey or brown and also tends to contain reddish, lateritic gravelly concretions with a varying proportion of silt and clay. Although all of the Niger Delta area is characterized by tropical rainfall conditions, annual rainfall ranges from $2000 \mathrm{~mm}$ in the freshwater zone to over $4000 \mathrm{~mm}$ at the coast which also accounts for nearly $85 \%$ of the annual rainfall. Thus the coastal and mangrove zones contain nearly $70 \%$ of the numerous marshes and back swamps that occupy as much as $50 \%$ by area of the entire delta region. Also they are usually submerged during the wet season (April to October). However the relatively less "wet" conditions in the freshwater zone coincide with the occurrence of lateritic or tropical red solids. These deltaic lateritic soils differ markedly from the other lateritic soils because of some mode of formation related peculiarities (Omotosho, 2015). Alabo et al. (1984) studied these soils in Port Harcourt area and its environs which belong to the freshwater zone. They referred to the soils as 'deltaic red soils' on the basis of their colour, one of the several identifying criteria for laterites and lateritic soils. These tropical red soils occur exclusively in the freshwater zone and are widely used in highway and other earthen work constructions, and as back fill materials. The performance of the soils for engineering construction in the delta region is varied. Early failure of pavements constructed with these soils is common. Studies by Alabo et al. (1984) showed that locally in Port Harcourt area, the soils belong to the A-2-7 class of AASHO classification and this correlates well with their good performance as fill materials. Adeyemi (2002) has emphasized the imperative of a comprehensive evaluation of any lateritic soils prior to utilization for any engineering purpose. This is because of the unique set of physical, chemical and engineering properties the soils exhibit in response to the different climatic, geomorphologic and geological conditions of their origin. Due to the abundance of these soils and ready availability, they have been widely used in the construction of foundations, roads, airfields, low-cost housing, 
and compacted fill in earth embankments. This affects their variable performance as soil materials for road earthwork, and often require stabilisation (Omotosho and Eze-Uzomaka 2008, Ugbe 2011, Adeyemi et al. 2015) compared to other matured tropical lateritic soils (Elarabi et al. 2013, Elsharief et al. 2013, Carvalho et al 2015, ) which achieve better success under mechanical compaction in engineering construction. Therefore, for engineering purposes it is important that the geological and engineering properties as predicted or derived from testing are reliable (Kamtchueng et al. 2015). This paper will attempt to determine the major oxide geochemistry and geotechnical properties of these red soils. The new data will help to classify the lateritic nature of the examined soils and also determine their quality as fill materials.

\section{Geological Setting}

The studied area is located in the freshwater geomorphologic zone of the eastern Niger which lies between latitudes $4^{\circ} 30^{\prime}$ and $5^{\circ} 20^{\prime}$ and longitudes $6^{\circ} 15^{\circ}$ and $7^{\circ} 35^{\prime}$ (Fig.1). The geology of the Niger Delta including its tectonic framework, stratigraphy and sedimentation pattern is well known from the published accounts of several authors, including Allen (1965) and Short and Stauble (1967), Doust and Omatsola (1990), Reijers et al 1997, Reijers (2011) and Nwajide (2013). The Niger Delta is a large arcuate delta of the destructive, wave dominated type. Its development is a function of the balance between the rate of sedimentation and the rate of subsidence. Tectonic evolution of the delta was controlled by Cretaceous fracture zones formed during the triple junction rifting and opening of the south Atlantic. The sedimentary fill of the southern Nigeria sedimentary basin was controlled by three major tectonic stages together with epirogenic movements which led to major episodes of transgressions and regressions. The cycles accounted for the sedimentary units in both the Cretaceous and Tertiary Southern Nigerian sedimentary basins, among which is the Niger Delta (Odigi, 2007). The delta represents the regressive phase of the third cycle of deposition which began during the Paleocene and has continued to the present day. The basin contains Cenozoic to Recent deposits emplaced in high energy constructive deltaic environments. The delta is underlain by three lithostratigraphic units comprising from bottom of Akata Formation deposited under marine conditions and consisting of shale. The formation has an approximate range of thickness from $0-6,000 \mathrm{~m}$ and ranges from Paleocene to Holocene in age. It is the main source rock in the petroliferous Niger Delta. Shale diapirism due to loading of poorly compacted, over-pressured, prodeltaic and delta-slope clays resulted in the deposition of the Akata Formation. It is overlain by a paralic facies of shale and sand intercalation known as Agbada Formation deposited under mixed marine and continental environments. This sequence consists of an upper predominantly sandy unit with minor shale intercalations and a lower shale unit which is thicker than the upper sandy unit. The Agbada Formation is over 10,000ft thick and ranges in age from Eocene to Recent. All hydrocarbon accumulations in the Niger Delta are found in this formation. It is a pro-delta deposit characterized by gravity tectonics structures such as shale diapirs, roll-over anticlines, collapsed growth fault crests, and steeply dipping closely spaced flank faults. The top Benin Formation, Oligocene to recent age, is predominantly sandy although some shale intercalations are common. It was deposited under continental conditions. Various types of Quaternary deposits overly the Benin formation especially in the coastal and Mangrove zone and their nature have been discussed extensively by Akpokodje (1989) and Tse and Akpokodje (2013). Generally they consist of a top stratum of clay, silt or organic matter and sand, silt-clay mixture overlying a sandy/sand substratum which occurs at variable depths, ranging from 5 to $30 \mathrm{~m}$ or more in the subsurface. 

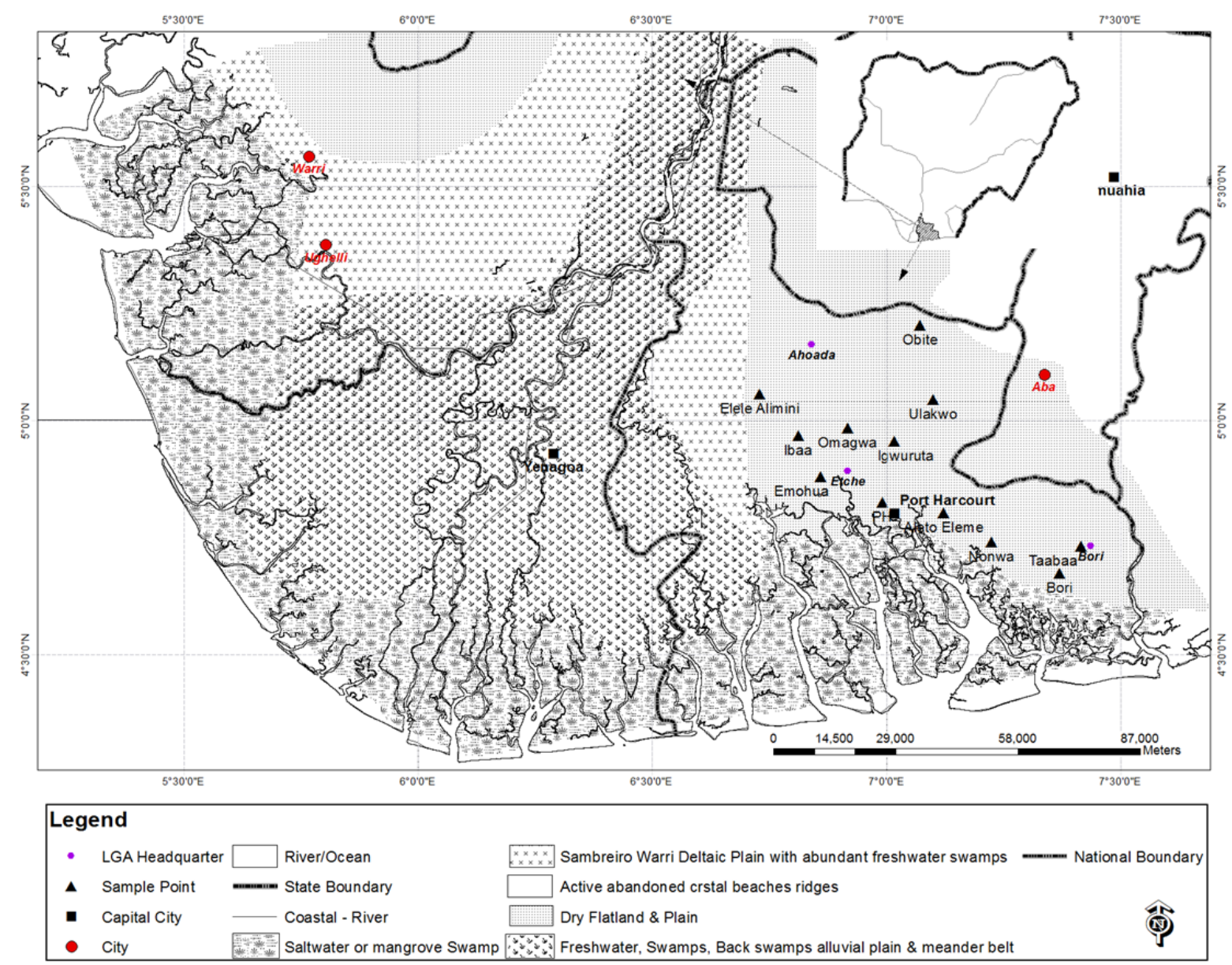

Figure 1. Map of Niger Delta showing geomorphologic zones and sampling points

In the freshwater zone, the Benin Formation is covered by appreciable thicknesses of red soils. Assez (1976) suggested they were formed as a result of the weathering of sedimentary deposits of sands and poorly cemented sandstones with some clay and their subsequent ferrugenisation. The dry flat land and plains is characterized by freshwater rivers, creeks and seasonal marshes. Soil profiles comprises of a top lateritic clay layer succeeded by poorly graded sand and gravel. The zone is comparatively the best drained of all the other geomorphic zones and is thus relatively drier. The permeability of soils is low to high and aquicludes, perched and normal aquifers are common. Overall, the soils have variable foundation potentials as discussed by Akpokodje (1979), Teme (2002), and Tse and Akpokodje (2013).

\section{Materials And Methods.}

Soil samples used for this study were obtained along major roads in areas which geomorphologically lie in the dry flatland and plains in the eastern Niger Delta along an east-west direction as shown in Fig. 1. The samples were collected from active and abandoned borrow pits used for mining of backfill and pavement materials by civil construction companies. The soils range from light yellow to greyish brown to reddish brown clayey-silty-sandy earth materials. At each location, three disturbed samples were collected at the bottom, middle and top in a vertical profile along the face of the pits which were first scraped to obtain fresh samples. The soils were described by visual inspection in the field and were subjected to laboratory tests according to methods and procedures specified by BS 1377 of 1990 . Classification and strength tests carried out included particle size distribution, Atterberg limits, linear shrinkage, specific gravity by density bottle method, standard proctor compaction test, quick undrained unconsolidated triaxial test in standard triaxial test cells $76 \mathrm{~mm}$ high and $38 \mathrm{~mm}$ in diameter, and soaked and unsoaked California Bearing Ratio (CBR). Sieve analysis first involved washing of the soil samples through ASTM sieve number $200(0.075 \mathrm{~mm}$ mesh) to separate sand fraction from the fines (clay and silt) fraction. Thereafter, mechanical sieve analysis was performed to separate the sand into the various 
particle sizes. The moisture content - density relationships of the soils were determined by the standard Proctor test where $3 \mathrm{~kg}$ of the soil was compacted in 3 equal layers in a cylindrical metal mould of volume $0.00956 \mathrm{~m}^{3}$ using a $4.5 \mathrm{~kg}$ rain falling through a height of $0.45 \mathrm{~m}$. Linear shrinkage tests were carried out to determine the water content at which no further decrease in the volume of the soil masses will not be experienced. The major oxides composition of the soils was determined by X-ray fluorescence analysis using Thermoscientific Advant 1200 model equipment. Results were used to determine the lateritic nature of the soils using the silica sesquioxide ratio presented by Rossiter (2004) as described in Alayaki (2015). Finally statistical regression analysis was performed on the test results and correlation coefficients tests were used to establish the relationship among the properties tested.

\section{Results}

A field examination and visual observation shows that the soils range from light yellow to greyish brown to reddish brown clayey-silty-sandy earth materials. The major oxides composition of the soils are shown in Table 1 . The soils are made up of 62.66 to 69.94 wt. $\%$ of $\mathrm{SiO}_{2}, 0.11$ to 0.32 wt.\% of $\mathrm{Fe}_{2} \mathrm{O}_{3}$, and 27.20 to 34.12 wt.\% of $\mathrm{Al}_{2} \mathrm{O}_{3}$. Thus quartz, iron and aluminium oxides are the dominant components of the soils. Results of the geotechnical properties of these tropical red soils which consist of variable proportions of gravel, sand, and fines fraction are shown in Table 2. Typical particle size distribution curves of the soils shown in Fig. 2 reveal that the amount of fines ranges from 22 to $76 \%$. Soils in Ulakwo and Ogrike have the least amount of fines while Igwuruta and Emohua have the highest. A quantitative measure of the range of soil particles in a given sample is the uniformity coefficient. This varies from 2 to 9 with most of the samples having values of below 5 indicating that the soils are poorly graded. The moisture-density relationship results are summarized in Fig. 3. Maximum dry density of 1680 to $1880 \mathrm{~kg} / \mathrm{m}^{2}$ were obtained at optimum moisture content (OMC) of 13 to $16 \%$. Soils in the northern and western northern parts of the study area attained the least MDD of approximately $1700 \mathrm{~kg} / \mathrm{m}^{3}$ at OMC of $15 \%$, while the ones in the south eastern axis from Igwuruta to Tabaa gave the highest MDD of approximately $1850 \mathrm{~kg} / \mathrm{m}^{3}$ at an average OMC of $13 \%$. Lateritic soils which give OMC between $8-10 \%$ and above $10 \%$ are rated by Philips (1952) as average to poor respectively for use under bituminous surfacing. Atterberg limits are important factors in the use of lateritic soils in pavement construction as sub-grade and sub-base materials. The average values of liquid limit of 26 to $48 \%$ classifies as clays of low to intermediate plasticity. Plasticity index range from 5 to $15 \%$. These are soils of low swelling potentials according to the Ola (1982) rating. Thus, when the Skempton activity was calculated from the results of the plasticity index and percentage of clay obtained from the hydrometer tests, values of 1.01 to 5.56 with an average of 1.23 were obtained (Table 3). These classify as normal to active clays of low to medium sensitivity (Skempton, 1953). The California Bearing Ratio (CBR) test is used in the empirical estimation of the bearing capacity of sub-grade and sub-base materials under soaked and dry conditions. The soaked and unsoaked CBR values range between 3-9\% and $14-38 \%$ respectively, and their relationship is graphically shown in Fig. 4.

Table 1. Major oxide geochemistry and silica:sesquioxide ratios

\begin{tabular}{lllllllllllll}
\hline Location & $\%$ & $\%$ & $\%$ & $\%$ & $\%$ & $\%$ & $\%$ & $\%$ & $\%$ & $\%$ & $\%$ & $\mathrm{SSR}$ \\
& $\mathrm{SiO}_{2}$ & $\mathrm{Fe}_{2} \mathrm{O}_{3}$ & $\mathrm{Al}_{2} \mathrm{O}_{3}$ & $\mathrm{MgO}$ & $\mathrm{CaO}$ & $\mathrm{NaO}$ & $\mathrm{K}_{2} \mathrm{O}$ & $\mathrm{MnO}_{2}$ & $\mathrm{~T}_{\mathrm{i}} \mathrm{O}_{2}$ & $\mathrm{P}_{2} \mathrm{O}_{5}$ & Total & \\
\hline Ogrike & 69.94 & 0.11 & 27.20 & 0.08 & 0.19 & 0.08 & 0.10 & 0.08 & 2.02 & 0.020 & 99.82 & 4.37 \\
Ahoada & 68.43 & 0.13 & 28.60 & 0.05 & 0.25 & 0.10 & 0.13 & 0.10 & 2.02 & 0.023 & 99.83 & 4.06 \\
Elele Alimini & 65.51 & 0.15 & 31.55 & 0.04 & 0.21 & 0.08 & 0.11 & 0.10 & 2.12 & 0.026 & 99.90 & 3.52 \\
Igwuruta & 66.43 & 0.18 & 30.60 & 0.11 & 0.25 & 0.10 & 0.13 & 0.07 & 2.01 & 0.017 & 99.90 & 3.69 \\
Ulakwo & 67.08 & 0.16 & 29.75 & 0.10 & 0.30 & 0.12 & 0.10 & 0.08 & 2.15 & 0.022 & 99.85 & 3.82 \\
Eleme & 68.22 & 0.20 & 28.45 & 0.06 & 0.37 & 0.10 & 0.16 & 0.05 & 2.24 & 0.030 & 99.88 & 4.07 \\
Nonwa & 66.83 & 0.32 & 30.09 & 0.10 & 0.29 & 0.11 & 0.15 & 0.06 & 2.05 & 0.029 & 99.88 & 3.74 \\
Bori & 62.66 & 0.24 & 34.12 & 0.07 & 0.28 & 0.14 & 0.14 & 0.09 & 2.19 & 0.018 & 99.95 & 3.09 \\
Tabaa & 64.88 & 0.17 & 31.80 & 0.08 & 0.33 & 0.09 & 0.12 & 0.05 & 2.21 & 0.032 & 99.76 & 3.45 \\
\hline
\end{tabular}

$\mathrm{SSR}=$ silica:sesquioxide ratio

Table 2. Geotechnical properties of the soils 


\begin{tabular}{|c|c|c|c|c|c|c|c|c|c|c|c|c|c|c|c|}
\hline $\begin{array}{l}\text { S/ } \\
\text { No }\end{array}$ & Location & GS & $\begin{array}{l}\text { LL } \\
(\%)\end{array}$ & $\begin{array}{l}\text { PL } \\
(\%)\end{array}$ & $\begin{array}{l}\text { PI } \\
(\%)\end{array}$ & $\begin{array}{l}\text { LS } \\
(\%)\end{array}$ & $\begin{array}{l}\% \\
\text { Fines }\end{array}$ & $\begin{array}{l}\% \\
\text { Sand }\end{array}$ & $\mathrm{CU}$ & $\begin{array}{l}\text { Cohesion } \\
\left(\mathrm{kN} / \mathrm{m}^{2}\right)\end{array}$ & $\begin{array}{l}\text { FA } \\
\left({ }^{\circ}\right)\end{array}$ & $\begin{array}{l}\mathrm{OMC} \\
(\%)\end{array}$ & $\begin{array}{l}\mathrm{MDD} \\
\left(\mathrm{Kg} / \mathrm{m}^{3}\right)\end{array}$ & $\begin{array}{l}\text { Soaked } \\
\text { CBR }\end{array}$ & $\begin{array}{l}\text { Unsoaked } \\
\text { CBR }\end{array}$ \\
\hline 1 & Ogrike & 2.68 & 30 & 23 & 7 & 7.7 & 31 & 69 & 9 & 160 & 3 & 15 & 1780 & 3.61 & 18.79 \\
\hline 2 & Obite & 2.66 & 35 & 24 & 11 & 7.5 & 50 & 51 & 7 & 20 & 23 & 16 & 1680 & 2.71 & 13.83 \\
\hline 3 & Abarikpo & 2.67 & 26 & 21 & 5 & 7.6 & 53 & 47 & 2 & 35 & 17 & 16 & 1710 & 3.61 & 15.48 \\
\hline 5 & $\begin{array}{l}\text { Elele } \\
\text { Alimini }\end{array}$ & 2.65 & 47 & 35 & 12 & 7.5 & 58 & 42 & 4 & 30 & 22 & 15 & 1700 & 5.11 & 14.13 \\
\hline 6 & Emohua & 2.67 & 41 & 32 & 9 & 7.7 & 76 & 22 & 3 & 60 & 14 & 15 & 1730 & 6.61 & 18.49 \\
\hline 7 & Ibaa & 2.68 & 44 & 33 & 11 & 7.5 & 51 & 51 & 5 & 135 & 5 & 15 & 1770 & 3.41 & 17.89 \\
\hline 8 & Omagwa & 2.68 & 48 & 33 & 15 & 7.5 & 60 & 41 & 1 & 60 & 14 & 15 & 1770 & 4.36 & 19.39 \\
\hline 9 & Igwuruta & 2.67 & 42 & 29 & 12 & 7.5 & 69 & 38 & 2 & 115 & 8 & 15 & 1820 & 5.56 & 24.80 \\
\hline 10 & Ulakwo & 2.67 & 40 & 33 & 7 & 7.5 & 37 & 67 & 5 & 120 & 12 & 14 & 1850 & 9.17 & 25.54 \\
\hline 11 & $\mathrm{PH}$ & 2.67 & 39 & 28 & 12 & 7.6 & 51 & 49 & 6 & 30 & 17 & 16 & 1690 & 3.76 & 13.68 \\
\hline 12 & Eleme & 2.66 & 34 & 24 & 10 & 7.7 & 43 & 58 & 7 & 150 & 6 & 14 & 1820 & 5.86 & 23.00 \\
\hline 13 & Nonwa & 2.67 & 28 & 24 & 10 & 7.7 & 51 & 49 & 6 & 40 & 25 & 14 & 1860 & 6.31 & 16.68 \\
\hline 14 & Bori & 2.67 & 34 & 28 & 12 & 7.7 & 46 & 54 & 5 & 130 & 10 & 14 & 1880 & 7.21 & 29.16 \\
\hline 15 & Taabaa & 2.66 & 40 & 29 & 11 & 7.8 & 62 & 39 & 2 & 100 & 7 & 13 & 1880 & 7.67 & 37.76 \\
\hline
\end{tabular}

Average results for 3 samples at each location. $\mathrm{GS}=$ specific gravity, $\mathrm{LL}=$ liquid limit, $\mathrm{PL}=$ plastic limit, $\mathrm{LS}=$ linear shrinkage, $\mathrm{CU}=$ coefficient of uniformity, $\mathrm{FA}=$ frictional angle

Table 3. Classification and description of soil activity (after Skempton 1953)

\begin{tabular}{lllllll}
\hline S/No & Location & $\begin{array}{l}\text { Clay } \\
\text { amount } \\
\%\end{array}$ & $\begin{array}{l}\text { Plasticity } \\
(\%)\end{array}$ & $\begin{array}{l}\text { Index } \\
\text { Activity } \\
\text { value }\end{array}$ & $\begin{array}{l}\text { Activity classification } \\
\text { Activity } \\
\text { description }\end{array}$ \\
\hline 1 & Ogrike & 5.73 & 7.4 & 1.29 & Active & Low sensitivity \\
2 & Obite & 4.30 & 11 & 2.56 & Active & Medium sensitive \\
3 & Abarikpo & 4.86 & 4.9 & 1.01 & Normal & Insensitive \\
5 & Elele Alimini & 5.08 & 12.8 & 2.51 & Active & Medium sensitive \\
6 & Emohua & 4.03 & 9.2 & 2.28 & Active & Medium sensitive \\
7 & Ibaa & 2.52 & 11 & 4.37 & Active & sensitive \\
8 & Omagwa & 2.68 & 14.9 & 5.56 & Active & sensitive \\
9 & Igwuruta & 5.08 & 12.4 & 2.47 & Active & Medium sensitivity \\
10 & Ulakwo & 1.38 & 7.2 & 5.21 & Active & sensitive \\
11 & Port Harcourt & 7.88 & 11.7 & 1.48 & Active & Low sensitivity \\
12 & Aleto Eleme & 6.11 & 10.2 & 1.66 & Active & Low sensitivity \\
13 & Nonwa & 4.28 & 8.00 & 1.87 & Active & Low sensitivity \\
14 & Bori & 6.41 & 9.7 & 1.86 & Active & Low sensitivity \\
15 & Taabaa & 10.08 & 10.60 & 1.05 & Normal & Low sensitivity \\
\hline
\end{tabular}




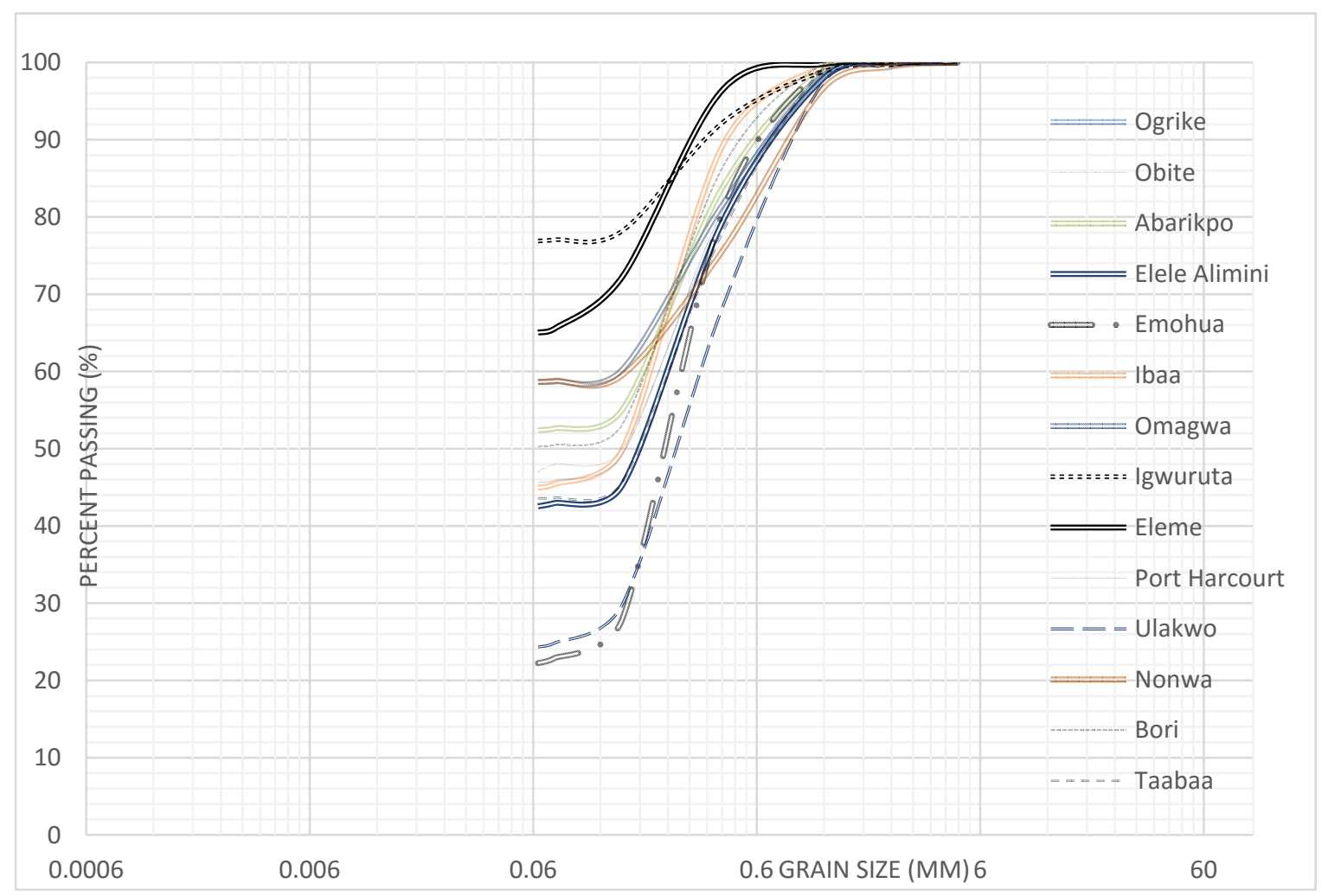

Figure 2. Particle size distribution of the soils

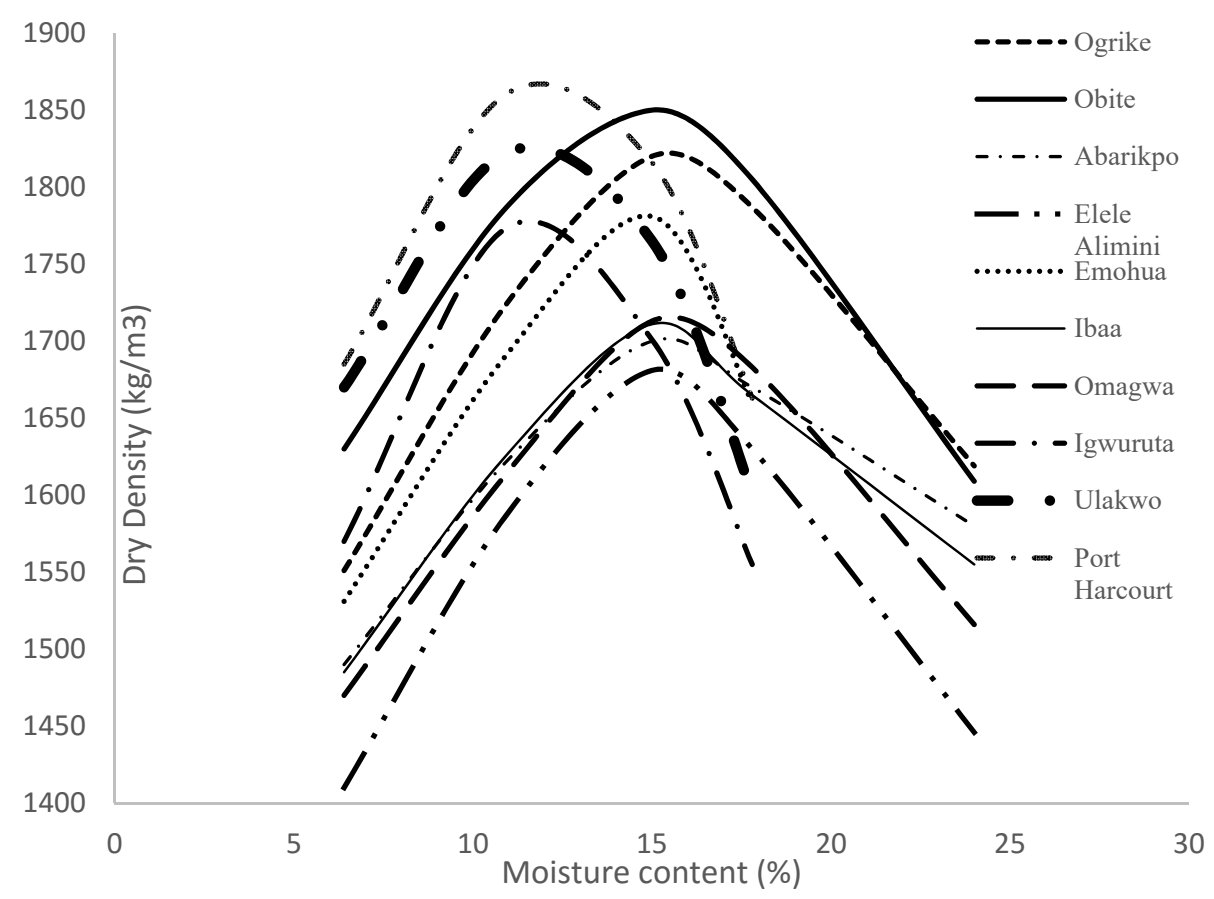

Figure 3. Density-moisture content relationships

\section{Discussions}

The studied soils are rich in oxides of silica, iron and aluminum, therefore the red color is derived from the presence of iron oxides. The relation between silica and oxides of iron and aluminium, is known as silica-sesquioxide ratio (Rossiter 2004). This ratio is extensively used as a criterion for the classification of soils 
as laterites. Soils are classified as true laterites if the ratio is less than 1.33 but ratios between 1.33 and 2.00 classify as lateritic soils whereas those with ratio above 2.00 are classified as non-lateritic tropically weathered soils. When the ratio was computed, the range of values fell between 3.09 and 4.37 indicating that the soils are non-lateritic. This agrees with the results of Akpokodje (1986) and Alayaki et al (2015) which show that the red deltaic soils are non-lateritic. The large amount of silica in proportion to the alumina indicates poor lateritisation (Rossiter 2004). Increase in sesquioxides ratios result in decrease in cation exchange capacity and moisture retentivity of soil. Sesquioxides accumulate in soil profiles as a result of leaching of silica. According to Gidigasu (1976), the high aluminum oxide content compared to iron oxides in soils is one of the features common with soils formed in a continuously wet climate characteristic of the Niger Delta. A higher degree of lateritisation is associated with higher specific gravity values which, for laterites, range from 2.50 to 3.60 (De Graf Johnson 1972). Also, laterite evolution increases with iron content and decreases in alumina content. These indicators imply that the soils in this study have not undergone any appreciable degree of lateritisation, given their relatively low specific gravity values of 2.65 to 2.68 and also the relative enrichment of aluminium oxide over iron oxides.

The more the fines proportion in a soil, the poorer the quality as a construction material. Fine grained soils in the silt and clay class may undergo volume changes on contact with water which results in weakening of the soil structure and consequent reduction in overall strength. The grading characteristics of soils are important factors for soils to attain high dry density when compacted. Well graded soils achieve very high density when compacted at the appropriate optimum moisture content. The larger the plasticity index of a soil, the greater the engineering problems associated with the use of the soil as an engineering material (e.g. foundation support, road sub-grades, etc.). Pavement waviness, a type of road failure which results from plastic flow of the underlying wet soil on application of axle load is common among the major paved roads in the study area. It occurs from the high fines content of the soils. The Nigerian Federal Ministry of Works and Housing specifications (1997) require that sub-base materials should have maximum values of $30 \%$ for liquid limit and plasticity index of $12 \%$. However, studies of superficial soils used in pavement construction in the Niger Delta have identified high fines content in the soils as one of the leading factors that promote early pavement failure in the region. The classification scheme developed by AASHO is a very useful guide to determine the quality of soils as subgrade materials for pavement construction. It utilizes texture and plasticity to rate the quality of a soil as subgrade material, decreasing from A-2 to A-7. The soils fall within the silt-clay class of sub-groups A-2-4 to A-7-6 of the AASHO classification scheme, with majority classifying in the A-2-7 and are thus rated as poor sub-grade materials. This is because texturally they are A-2 soils but are A-7 in plasticity. It implies they can achieve low to moderate performance as sub-grade materials. The Nigerian Federal Ministry of Works (1997) specifies minimum values of soaked and unsoaked CBR at $10 \%$ and $15 \%$ respectively for sub-grade soils compacted using standard proctor method. This means soaking will cause reduction in the strength of the soils because the soaked CBR falls below the minimum requirements. Under unsoaked conditions, the soils will retain the field compactive strength. On the other hand, the CBR should be less than $30 \%$ after 24 hours of soaking at OMC indicating that the soils are not suitable for the sub-base. Under quick unconsolidated undrained conditions, triaxial test gave cohesion ranging from 20 to $180 \mathrm{kN} / \mathrm{m}^{2}$ and frictional angles of 6 to $23^{\circ}$. To establish the relationship between the various geotechnical properties of the soils, a regression analysis was attempted. Results summarized in Table 4 indicate that there is high positive correlation between unsoaked CBR and OMC $(\mathrm{r}=0.77)$, unsoaked CBR and MDD $(\mathrm{r}=0.83)$, soaked CBR and MDD $(\mathrm{r}=0.08)$ and shear strength and MDD $(\mathrm{r}$ $=0.71)$. This implies an increase in one variable is accompanied by an increase in the other and indicates a direct proportional relationship. However, a highly negative correlation exists between soaked CBR and OMC $(\mathrm{r}=$ $-0.77)$, and between shear strength and OMC $(\mathrm{r}=-0.58)$. This means an increase in one variable is accompanied by a decrease in the other, indicating an inversely proportional relationship. The overall implications of these results is that although these non-lateritic soils possess fair to good engineering properties, considerable strength reduction will be experienced under wet conditions. Due to high precipitation prevalent in the Niger Delta, adequate drainage at the shoulders of the roads will be imperative during construction to forestall the loss of subgrade strength due to ingress of water into the pavement 
Table 4. Bivariate relationship between some geotechnical properties

\begin{tabular}{lcl}
\hline Parameter & Regression Equation & $\mathrm{r}$ \\
\hline Soaked CBR vs OMC & $\mathrm{y}=27.77+9(1.52) x$ & -0.77 \\
Unsoaked CBR vs OMC & $\mathrm{y}=18.70+(-0.02) x$ & 0.77 \\
Soaked CBR vs MDD & $\mathrm{y}=-30.10+(0.02) x$ & 0.08 \\
Unsoaked CBR vs MDD & $\mathrm{y}=-108.4+(0.07) x$ & 0.83 \\
Shear Strength vs OMC & $\mathrm{y}=650.81+(-32.44) x$ & -0.58 \\
Shear Strength vs MDD & $\mathrm{y}=-751.86+(0.52) x$ & 0.71 \\
\hline
\end{tabular}

The classification scheme developed by AASHO is a very useful guide to determine the quality of soils as subgrade materials for pavement construction. It utilizes texture and plasticity to rate the quality of a soil as subgrade material, decreasing from A-2 to A-7. The soils fall within the silt-clay class of sub-groups A-2-4 to A-7-6 of the AASHO classification scheme, with majority classifying in the A-2-7 and are thus rated as poor sub-grade materials. This is because texturally they are A-2 soils but are A-7 in plasticity. It implies they can achieve low to moderate performance as sub-grade materials. The California Bearing Ratio (CBR) test is used in the empirical estimation of the bearing capacity of sub-grade and sub-base materials under soaked and dry conditions. The soaked and unsoaked CBR values range between $3-9 \%$ and $14-38 \%$ respectively, and their relationship is graphically shown in Fig. 4.

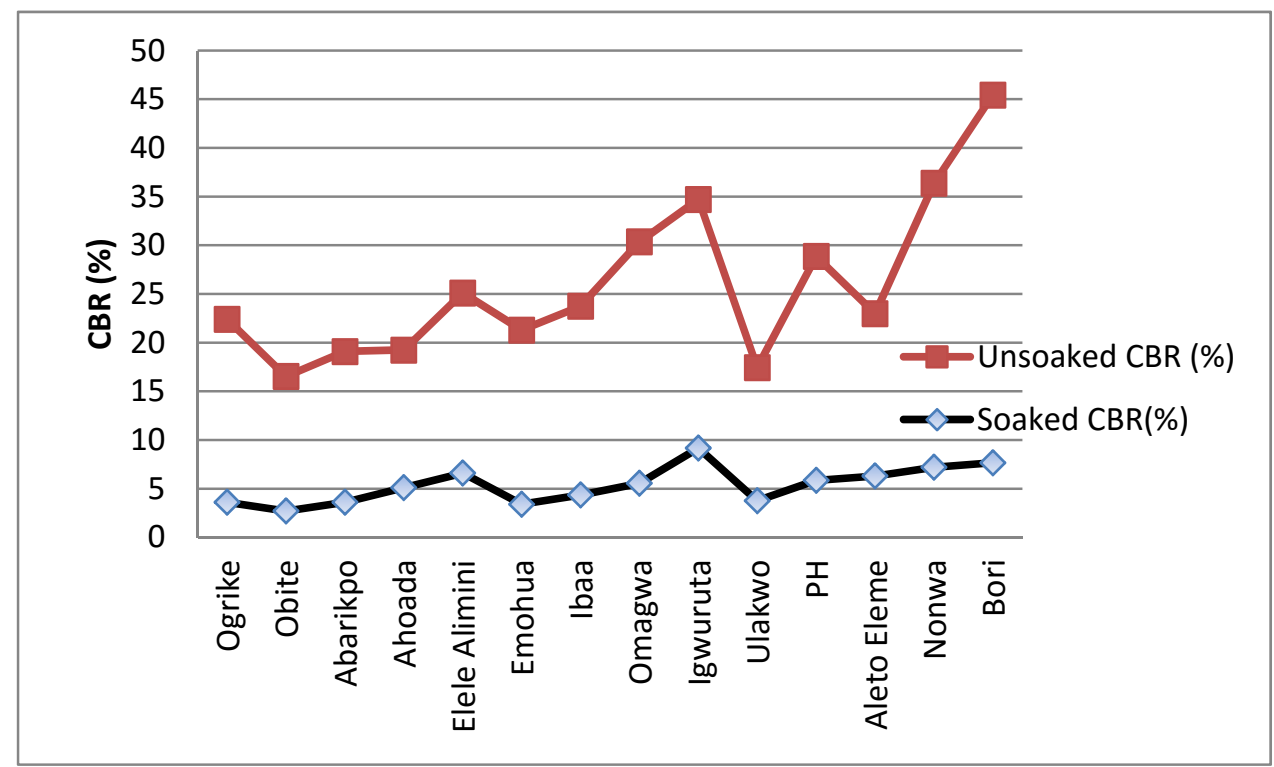

Figure 4. Relationship between unsoaked and soaked CBR

The Nigerian Federal Ministry of Works (1997) specifies minimum values of soaked and unsoaked CBR at 10\% and $15 \%$ respectively for sub-grade soils compacted using standard proctor method. This means soaking will cause reduction in the strength of the soils because the soaked CBR falls below the minimum requirements. Under unsoaked conditions, the soils will retain the field compactive strength. On the other hand, the CBR should be less than $30 \%$ after 24 hours of soaking at OMC indicating that the soils are not suitable for the sub-base. Under quick unconsolidated undrained conditions, triaxial test gave cohesion ranging from 20 to $180 \mathrm{kN} / \mathrm{m}^{2}$ and frictional angles of 6 to $23^{\circ}$. To establish the relationship between the various geotechnical properties of the soils, a regression analysis was attempted. Results summarized in Table 4 indicate that there is high positive correlation between unsoaked CBR and OMC $(\mathrm{r}=0.77)$, unsoaked CBR and MDD $(\mathrm{r}=0.83)$, soaked CBR and MDD $(r=0.08)$ and shear strength and MDD $(r=0.71)$. This implies an increase in one variable is accompanied by an increase in the other and indicates a direct proportional relationship. However, a highly negative correlation exists between soaked CBR and OMC $(r=-0.77)$, and between shear strength and $\mathrm{OMC}(\mathrm{r}=-0.58)$. This means an increase in one variable is accompanied by a decrease in the other, indicating an inversely proportional relationship. The overall implications of these results is that although these non-lateritic soils possess fair to good engineering properties, considerable strength reduction will be experienced under wet 
conditions. Due to high precipitation prevalent in the Niger Delta, adequate drainage at the shoulders of the roads will be imperative during construction to forestall the loss of subgrade strength due to ingress of water into the pavement layers below the wearing surface.

\section{Conclusions}

The non-lateritic, tropical red soils in the dry flat lands and plains of the Niger Delta are composed of generally poorly graded soils consisting of clay, silt and sand. They yield moderate dry density when compacted at the optimum moisture content of the standard proctor method and are fair to good back fill material for pavement construction. The CBR values indicate significant strength reduction of the soils when soaked. Therefore adequate drainage must be provided during road construction to prevent the ingress of water into layers under the pavement. Generally, the poor soil properties may be improved by stabilization to increase their usefulness in pavement construction.

\section{References}

Adeyemi, G. O. (2002). Geotechnical properties of lateritic soils developed over quartz schist in Ishara area, Southwestern Nigeria. Journal of Mining and Geology, 38, 65-69

Adeyemi, G. O., Afolagboye, L.O., \& Chukwuemeka, C. A. (2015). Geotechnical properties of non-crystalline coastal plain sand derived lateritic soils from Ogua, Niger Delta, Nigeria. African Journal of Science, Technology, Innovation $\quad$ and 230-235. http://dx.doi.org/10.1080/20421338.2015.1078105

Akpokodje, E. G. (1986): The Geotechnical Properties of Laterite and Non-Laterite Soils of South-Eastern Nigeria and their Evaluation for Road Construction. Bull. Int. Assoc. Eng. Geol., 33, 115 - 121.

Akpokodje, E. G. (1989). Preliminary Studies on the geotechnical characteristics of Niger Delta subsoils. Engineering Geology, 26, 247-257.

Alabo, E. H., FitzJohn, W. H., \& Ogaree, F. A. (1984). Geotechnical Index properties of a Tropical Red Soil from parts of the Eastern Niger Delta, Nigeria. Journal of Mining and Geology, 21(1\& 2), 35-39.

Alayaki, F., Al-Tabbaa, A., \& Ayotamuno, J. (2015). Defining Niger Delta Soils: Are They Laterites? Civil and Environmental Research, 7(5), 21-26

Assez, L. O. (1976). Review of Stratigraphy, Sedimentation and Structure of the Niger. Kogbe (Ed.) Geology of Nigeria. Elizabethan pub. Co. Lagos. 436pp.

ASTM, American Society for Testing and Materials. (1992). Standard Method for Classification of Soils for Engineering Purposes (Unified Soil Classification System): D2487, American Society for Testing and Materials publication.

British Standards Institution-BS 1377. (1990). Methods of testing for soils for civil engineering purposes. BSI London

Carvalho J. C, de Rezende, L. R., Cardoso, F. B., Lucena, L. C., Guimarães, \& Valencia, R. C. (2015). Tropical soils for highway construction: Peculiarities and considerations. Transportation Geotechnics, 5, 3-19

De Graft-Johnson, J. W. S. (1972). Lateritic gravel evaluation of road construction. J. soil Mech. Div. Amst. Soc. Civil Eng., 98, 1245-1265.

Doust, H., \& Omatsola, E. (1990) Niger Delta: in J. D. Edwards and P.A. Santogrossi, Eds. Divergent/passive margin basins: AAPG Memoir, 48, p. 239-248.

Elarabi, H., Taha, M., \& Elkhawad, T. (2013). Some geological and geotechnical properties of lateritic soils from Muglad Basin located in the South-Western Part of Sudan. Research Journal of Environmental and Earth Sciences, 5(6), 291-294

Elsharief, A. M., Elhassan, A. A. M., \& Mohamed, A. E. M. (2013). Lime Stabilization of Tropical Soils from Sudan for Road Construction. Int. J. of GEOMATE, 4 (2) (Sl. No. 8) 533-538

Federal Ministry of Works and Housing. (1997). Nigerian General Specification for Roads and Bridges (Revised Edition), 2, 137-275.

Gidigasu, M. D. (1976). Laterite soil Engineering. Elsevier Scientific Publishing Company, Amsterdam Oxford, New York.

Gidigasu, M. D. (1983). Development of acceptance specifications for tropical gravel paving materials. Eng. Geo., 19, 213-240. 
Kamtchueng B. T., Onana, V. L., Fantong W. Y., Ueda A., Ntouala R. F. D., Wongolo, M. H. D., Ndongo, G. B., Ze, A. N., Kamgang, V. K. B., \& Ondoa, J. M. (2015). Geotechnical, chemical and mineralogical evaluation of lateritic soils in humid tropical area (Mfou, Central-Cameroon): Implications for road construction. International Journal of Geo-Engineering, 6, 1 http://dx.doi.org/10.1186/s40703-014-0001-0

Nwajide, C. S. (2013). Geology of Nigeria’s Sedimentary Basins. CSS Bookshops Limited. Lagos.

Odigi M. I. (2007). Facies Architecture and Sequence Stratigraphy of Cretaceous Formations, Southeastern Benue Trough, Nigeria (Unpublished PhD Thesis). University of Port Harcourt, Nigeria.

Ola, S. A. (1982). Mechanical properties of concretionary laterites from rainforest and savannah zones of Nigeria. Bull. Of Int. Assoc. of Eng. Geol., 21, 21-26

Omotosho, O. (2015). Effects of Stabilisation on the performance of Deltaic Lateritic Soils as a Road Pavement Material. University of Nigeria Institutional repository. Theses and Dissertations. Retrieved from http://repository.unn.edu.ng:8080/jspui/handle/123456789/1117

Omotosho, O., \& Eze-Uzomaka, O. J. (2008). Optimal stabilization of deltaic laterite. J. S. Afr. Inst. Civil Eng., 50(2), 10-17.

Reijers, T. J. A. (2011). Stratigraphy and Sedimentology of the Niger Delta. Geologos, 17(3), 133-162.

Reijers, T. J. A., Petters, S. W., \& Nwajide, C. S. (1997). The Niger Delta Basin. In R. C. Selley (Ed.): African basins. Sedimentary Basins of the World (Elsevier, Amsterdam), 3, 151-172

Rossiter, D. G. (2004). Digital soil resource inventories: status and prospects. Soil Use \& Management, 20(3),296-301

Short, K. C., \& Stauble, A. J. (1967). Outline of the geology of the Niger Delta, Bull. Americ. Ass. Petrol. Geol., $51,761-779$.

Skempton, A. W. (1953). The colloidal activity of clays. Proceedings of the third International Conference of soil Mechanics and Foundation Engineering. Zurich, 1, 57-60

Teme, S. C. (1999). Some geotechnical considerations for siting of land jetties (Ferry Terminals) in the Niger Delta region, Nigeria. $35^{\text {th }}$ Annual Conference of Nig. Min. and Geosc. Soc. Programme and Book of abstracts. P. 29.

Teme, S. C. (2002). Geotechnical considerations on foundations in the Niger Delta. Paper presented at the special technical session, 39th Annual International Conference of the Nigeria Mining and geosciences Society, NMGS. Port Harcourt, Nigeria.

Tse, A. C., \& Akpokodj, E. G. (2010). Subsurface Soil Profiles in Site Investigation for Foundation Purposes in Parts of the Mangrove Swamps of the Eastern Niger Delta. Journal of Mining and Geology, 46(1), 79-92

Ugbe, F. C. (2011). Basic Engineering Geological Properties of Lateritic Soils from Western Niger Delta. Research Journal of Environmental and Earth Sciences, 3(5), 571-577

\section{Copyrights}

Copyright for this article is retained by the author(s), with first publication rights granted to the journal.

This is an open-access article distributed under the terms and conditions of the Creative Commons Attribution license (http://creativecommons.org/licenses/by/4.0/). 